\title{
Şizofreni Hastalığına Sahip Bireylerin Çalışma Hayatı Konusunda Yaşadıkları Güçlükler
}

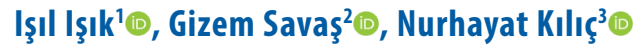

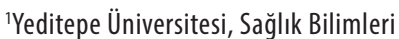
Fakültesi, Hemşirelik Bölümü, İstanbul, Türkiye ${ }^{2}$ Trakya Üniversitesi Tıp Fakültesi Hastanesi, Hemşire, Edirne, Türkiye ${ }^{3}$ Gebze Fatih Devlet Hastanesi, Hemşire, Kocael, Türkiye

Işıl Işık,Dr. Öğr. Üyesi Gizem Savaş, Hemşire Nurhayat Kılıç, Hemşire
İletişim:

Dr. Öğr. Üyesi Işıl lşık

Yeditepe Üniversitesi Sağık Bilimleri Fakültesi Hemşirelik Bölümü, İstanbul, Türkiye

Tel: $+902165780000 / 3255$

E-Posta: isil.isik@yeditepe.edu.tr
Gönderilme Tarihi : 20 Kasım 2017

Revizyon Tarihi ： 04 Aralık 2017

Kabul Tarihi ： 06 Aralık 2017

\section{ÖZET}

Bu çalışma şizofreni hastalarııın iş bulma ve iş hayatında yaşadıkları güçlükleri belirlemek amacılla fenomenolojik tipte yapııııı̧ bir araştırmadır. Araştırma, amaca yönelik örneklem seçme yöntemi ile İstanbul'da bulunan Avrasya Şizofreni ve Dünya Şizofreni Dernekleri'ne üye olan, araştırmaya dâhil edilme kriterlerine uyan ve araştıımaya katılmayı yazılı ve sözlü olarak kabul eden, 12 hasta ile yapıımıştır. Araştırmanın verileri 5 Eylül 2016-17 Mayıs 2017 tarihleri arasında belirlenen hastalarla yaklaşık 45'er dakikalık görüşmeler yapılarak toplanmıştır. Bireysel derinlemesine görüşmeler iç̧i literatür doğrultusunda araştırmacılar tarafından geliştirilen 17 soruluk yarı yapılandııııış form kullanılmıştır

Yapılan görüşmeler sonucunda hastaların çalışamama nedenleri, çalışmanın hasta üzerine etkileri ve çözüm önerileri olmak üzere toplam 3 ana tema ve bu temalar için alt temalar belirlenmişstir. Çalışmama nedenleri adlı tema için hastalığın çalışma hayatına etkisi, hastaların işe alınmamaları, engellilik maaşının çalışma durumunda kesilmesi ve damgalanma nedeniyle iş hayatında yaşanan güçlükler olmak üzere 4 alt tema belirlenmiştir Çalışmanın hasta üzerine etkileri adlı tema için çalışmanın olumlu etkileri ve çalışmamanın olumsuz etkileri olmak üzere 2 alt tema belirlenmiştir çözüm önerileri adlı tema için ise hastalığa uygun işler, halkın eğitimi, derneklerin artırılması ve devletle ilgili çözümler olmak üzere 4 alt tema belirlenmiştir. Hastaların ifadeleri doğrultusunda şizofreni hastalarının aldıkları engelli maaşı kesildiği için bir işe girmeye çekindikleri, damgalandıkları için işe alınmadıkları ve işe alınanların iş ortamında damgalanma yaşaması nedeniyle çalışmamayı tercih ettikleri belirlenmiştir HastaIarın çalışma hayatına ait sorunların çözümü konusunda girişimler yapılması ve damgalamayı azaltııı uygulamalar için harekete geçilmesi gerektiğini düşündükleri görüldü.

Sonuç olarak şizofreni tanısı alan hastaların her alanda olduğu gibi iş alanında da damgalanmakta ve ekonomik özgürlüklerini kazanamamaktadırlar.

Anahtar sözcükler: Şizofreni tanılı hastalar, iş hayatı, ruh sağlığı hemşiresi, damgalanma

\section{THE DIFFICULTIES THAT INDIVIDUALS WITH SCHIZOPHRENIA FACE IN BUSINESS LIFE}

\section{ABSTRACT}

This study is a research based on a phenomenological type in order to determine the difficulties that schizophrenics face in employment and business life. The research was conducted with 12 patients who were members of the Eurasian Schizophrenia and World Schizophrenia Associations with the sample selection method for the purpose, who met the criteria for inclusion in the research and agreed to participate in the research either written or oral. The data of the study were collected by interviewing patients who were identified between September, 52016 and May, 17 2017, for about 45 minutes. For individual in-depth interviews, A semi-structured form of 17 questions developed by the researchers in the direction of the literature was used.

As a result of the interviews, a total of 3 main themes and sub-themes have been determined for the following: the reasons for not working, the effects of the study on the patient and the solution suggestions. Four sub-themes have been identified for the theme "reasons for not working": the effect of the disease, the lack of hiring, the severance of salary and the difficulties in business life due to stigmatization. Two sub-themes have been identified for the theme of the effects of working on patients: the positive effects of working and the negative effects of working. For the theme of solution suggestions, four sub-themes have been determined including work that is appropriate for the disease, education of the public, an increase of associations and State-related solutions. In terms of patients' expressions, it has been determined that schizophrenia patients prefer not to work because they have a disability wage cut off, they are not hired because they are stigmatized, and they prefer not to work because of stigmatization in the business environment. It has been seen that patients think that it is necessary to take actions for the solutions of the problems of working life and for the applications to reduce the stigmatization.

As a result, people with schizophrenia are stigmatized in the field of work as well as in all areas, and they cannot gain their economic freedom.

Keywords: Patients with schizophrenia, business life, mental health nurse, stigmatization 
izofreni, genellikle gençlik yıllarında baş gösteren, büyük ölçüde yeti yitimine sebep olan, kişide belirgin halüsinasyon ve hezeyanlara neden olan nöropsikiyatrik bir hastalıktır $(1,2,3)$. Şizofreni hastalığı sebebiyle bireylerin soyut anlamda öğrenme yetileri bozulabilmekte ve dikkat eksikliği oluşabilmektedir. Halüsinasyonları veya sanrıları sebebiyle sürekli dikkatleri dağılmakta ve dikkatlerini belirli bir konu üzerinde toplamakta zorlanmaktadırlar $(3,4)$. Ayrıca şizofrenili bireyler ani ve beklenmedik davranışlarda da bulunabilmektedirler (3). Bu da hastalık hakkında bilgi sahibi olmayan bireylerin şizofreni tanısı alan bireylerden zarar görmekten ya da ruhsal hastalığın kendilerinde de olabilme ihtimalinden korkmasına ve onları damgalamalarına neden olmaktadır (5).

Şizofreni hastalarının yaşamını büyük ölçüde etkileyen bu damgalanma durumu, hayatlarının her alanında etkisini göstermektedir. Gerek hastaların tedavi olmak için hastaneye yatmayı kabullenmeleri konusunda, gerek özel hayatlarında gerekse çalışma hayatlarında damgalanmak şizofrenili bireylerin yaşam kalitesini düşürmektedir. Toplum içindeki "şizofreniler saldırgandır" imajı özellikle bu hastaların iş bulma ya da çalıştıkları işte tutunabilmeleri açısından zorlandıkları konulardan birisidir $(4,6)$. Türkiye'de yapılan epidemiyolojik bir araştırmada katılımcıların \%46,8'i şizofrenili birey ile çalışmayacağını belirtmiş̧tir (7).

Bireylerin işe girişte hastalıklarını söyleme zorunluluğu olmamasına rağmen hasta oldukları anlaşıldığında çalışıyorlarsa işlerini kaybedebilir ya da en başta işe alınmayabilirler. Hasta bireyler çalışamayınca da ekonomik kayıplar ortaya çıkmakta ve bu da yaşam kalitelerini etkilemektedir (8). Doğanavşargil'in (2009) yaptığı bir araştırmada şizofrenilerin $\% 53,5^{\prime}$ inin çalıştığı, çalışanların ise $\% 74,4^{\prime}$ ünün düşük maaşlarla çalıştıkları saptanmıştır (7).

Şizofreni hastalarının bütün bu sıkıntılarını en çok gören ve şahit olan gruplardan biri ise hemşirelerdir. Özellikle sahada çalışan hemşireler hastalarla yaptıkları görüşmeler sonucunda bizzat kendilerinden bu problemleri duymaktadırlar. İnsana bütüncül olarak bakan hemşirelerin bu hastalar için de en önemli görevlerinden biri damgalamayı azaltmak ve yaşam kalitelerini arttırmaktır (9). Ancak ülkemizde bu konuda yapılmış çalışma sayısı oldukça azdır. Bu nedenle araştırmanın, ülkemizdeki bu açığa dikkat çekmesi, hemşirelerin bu konuda yapacakları çalışmalara ışık tutması, benzer çalışmalar ve konu hakkında düzenlenecek eğitimler açısından yol gösterici olacağı düşünülmektedir.
Bu çalışma ile amaçlanan, şizofreni hastalarının iş bulma ve iş hayatında yaşadıkları güçlüklerin belirlenerek hastaların bu sorunların çözümü konusundaki fikirlerinin açığa çıkartılmasıdır.

\section{Araştırma soruları}

Hastalık bireylerin çalışma hayatını ne kadar etkiliyor?

Hastalık bireylerin işe alınma durumlarını ne kadar etkiliyor?

Damgalanma hastaları iş hayatında ne kadar etkiliyor?

Bir işte çalışmak bireylerin hayatını olumlu ve olumsuz olarak ne kadar etkiliyor?

\section{Gereç ve yöntem}

\section{Araştırmanın tipi}

Bu çalışma İstanbul'da iki şizofreni derneğine üye şizofreni tanısı alan hastalarının iş bulma ve iş hayatında yaşadıkları güçlükleri ve bu sorunların ortadan kaldırılması konusundaki düşüncelerini belirlemek amacıyla tanımlayıc tipte yapılmış kalitatif bir araştırmadır.

\section{Araştırmanın evreni ve örneklemi}

Örneklem seçiminde amaca yönelik örneklem seçim yöntemlerinden ölçüt örnekleme yöntemi kullanılmıştır. Ölçüt örnekleme örneklemin, problemle ilgili olarak belirlenen niteliklere sahip kişiler, olaylar, nesneler ya da durumlardan oluşturulmasıdır ve araştırmamızda örneklem seçimi ile ilgili olarak belirlenen nitelik şizofreni tanısı almış olmak olarak belirlenmiştir. Örneklemi Avrasya Şizofreni Derneği ve Dünya Şizofreni Derneği'ne üye olan ve araştırmaya katılmayı kabul eden 12 hasta oluşturmuştur. Araştırmanın örneklemini 1 tanesini kadın, 11 'ini erkek hasta oluşturmuştur. .

\section{Araştırmaya dâhil olma kriterleri}

Okur-yazar olma, 18-65 yaş arasında olma, çalışmaya katımaya gönüllü olma, DSM-IV'e göre en az bir yıllık şizofreni tanısı almış olma araştırmaya dâhil olma kriterleridir.

\section{Veri toplama aracı}

Araştırma verileri araştırmacılar tarafından literatür $(4,9)$ doğrultusunda geliştirilen yarı yapılandırılmış bireysel derinlemesine görüşme formu kullanılarak toplanmıştır. Hastanın sosyodemografik özelliklerinden 8 adet, hastalığı, bu hastalığın iş hayatına yansımaları ve iş hayatında damgalanmaya yönelik çözüm önerileri hakkında 8 adet olmak üzere toplamda 16 adet açık uçlu soru sorulmuştur. Toplam 16 sorudan oluşan yarı yapılandırılmış görüşme formunda hastayı tanıtıcı yaş, medeni durum, çocuğunun 
olup olmadığı, varsa kaç çocuğunun olduğu, kimlerle yaşadığı, eğitim durumu, mesleği ve şu anda çalışıp çalışmadığı da sorulmuştur. Hastaların hastalığı ve hastalığının çalışma hayatına etkilerini anlamak amacıyla da hastalığının ne zaman ve nasıl başladığı, ilk tanı konulduğunda neler hissettiği ve çalışıp çalışmadığı, şu anda çalışmıyorsa bunun nedenleri, hastalığın maddi yükü, hastalığının çalışma durumunu nasıl etkilediği, en son çalıştığı yerde hastalığı yüzünden damgalanıp damgalanmadığı, tedavi döneminden sonra iş başvurularının nasıl sonuçlandığı ve bu hastalığın iş bulmada önünde engel olduğunu düşünüp düşünmediği, hastaların tüm bu sorunlar için çözüm önerilerinin neler olabileceğini belirlemeye yönelik sorulardan oluşmaktadır.

\section{Verilerin toplanması}

Öncelikle dernekle görüşülüp dâhil olma kriterlerine uyan hastalar belirlenmiş ve belirlenen hastalardan çalışmaya katılmaya gönüllü olan 12 hastayla görüşme saatleri ayarlanmıştır. Araştırma 5 Eylül 2016-17 Mayıs 2017 tarihleri arasında hastalarla belirlenen görüşme saatleri içerisinde gerçekleştirilmiştir. Her hasta için yaklaşık 45 dakikalık görüşme saati ayrılmıştır. Görüşmeler ses kaydına alınmış ve bilgisayar ortamında aktarılmıştır.

\section{Verilerin değerlendirilmesi}

Bilgisayar ortamına aktarılan ses kayıtları birbirinden bağımsız 3 araştırmacı tarafından çözümlenmiştir. Tematik analiz yöntemi kullanılarak temalar ve alt temalar belirlenmiştir.

\section{Araştırmanın etik boyutu}

Araştırma uygulanmadan önce gerekli etik kurul izni Yeditepe Üniversitesi Klinik araştırmalar Etik Kurulu'ndan 37068608-6100-15-1278 sayılı etik kurul izni ve derneklerden yazılı kurum izinleri alınmıştır. Uygulama sırasında ise etik kurallara uymak amacıyla çalışmaya katılmak isteyen hastalara açıklama yapılmış ve hastalardan yazılı ve sözlü onam alınmıştır.

\section{Bulgular}

\section{Bireysel derinlemesine görüşmeler yoluyla toplanan} verilerin analizi sonucu hastaların çalışamama nedenleri, çalışmanın hasta üzerine etkileri ve çözüm önerileri olmak üzere toplam 3 ana tema ve bu temalar için alt temalar belirlenmiştir. Çalışmama nedenleri adlı tema için hastalığın çalışma hayatına etkisi, hastaların işe alınmamaları, engellilik maaşının çalışma durumunda kesilmesi ve damgalanma nedeniyle iş hayatında yaşanan güçlükler olmak üzere 4 alt tema belirlenmiştir Çalışmanın hasta üzerine etkileri adlı tema için çalışmanın olumlu etkileri ve çalışmamanın olumsuz etkileri olmak üzere 2 alt tema belirlenmiştir Çözüm önerileri adlı tema için ise hastalığa uygun işler, halkın eğitimi, derneklerin artırılması ve devletle ilgili çözümler olmak üzere 4 alt tema belirlenmiştir

\section{Çalışamama nedenleri}

Şizofreni hastalığına sahip 12 kişiyle bireysel derinlemesine görüşme yöntemi ile yapılan görüşmelerde elde edilen bilgiler sonucunda ortaya çıkan en güçlü temalardan biri hastaların çalışmama nedenleridir. Çalışmama nedenleri adlı ana tema 4 alt temadan oluşmaktadır. Bunlar; hastalığın etkisi, işe alınmamaları, maaşın kesilmesi ve damgalanma nedeniyle iş hayatında yaşanan güçlüklerdir.

\section{Hastalığın etkisi}

Yapılan görüşmeler sonucunda bireyler hastalığın çalışma hayatlarına nasıl etki ettiği ile ilgili görüşlerini belirtmişlerdir. Bazı bireyler çabuk sinirlenme, dikkati odaklamakta güçlük, uykuda artış gibi bazı hastalık semptomlarının çalışma hayatı koşullarına uyum sağlamalarını güçlendirdiğini bildirmişlerdir. Bu konuda aşağıda bazı bireylerin ifadeleri yer almaktadır:

"Hastalığım şöyle oldu, işten çıkarttılar, çünkü kendimi zapt edemiyordum orada. Personele kötü davranıyordum. Bir tanesine dedim, senin kafanı keserim dedim mesela beni dinlemezsen. Ondan sonra baktım olacak gibi değil, orada noktayı koydum ve bir daha da çalışma hayatına dönmedim." (43, erkek, daha önce çalışmış, bekâr)

"Sabah kalkmakta güçlük çekiyorum. Bir de uyum göstermekte zorlanıyorum, sıkılıyorum. Mesela burada yarım saat durayım yarım saat sonra beni bulamazsın." (47, erkek, daha önce çalışmış, evli)

\section{Işe alınmamaları}

Bireysel derinlemesine görüşme yapılan bireylerin çalışamama nedenlerinden birinin de işverenlerin onları işe almamaları olduğu belirlenmiştir. Özellikle hastalıkları nedeniyle damgalama yaşadıklarını ve işe alımlarda hastalıkları nedeniyle zorluklar yaşadıklarını belirtmişlerdir. Engelli kadrosundan işe alınma konusunda da birtakım zorluklar yaşadıklarını, işverenlerin genellikle fiziksel engelli kişileri tercih ettiklerini bildirmişlerdir. Aşağıda bu konuya örnek olarak bazı katılımcıların ifadeleri bulunmaktadır:

"Damgalama var. Hasta olduğunuz zaman diyorlar ki sen birini kesersin öyle tanıyorlar bizi. Bir yer vardı resepsiyonistlik başvurusunda bulundum. Emekli arıyorlardı ben emekliyim dedim. Adam baktı tipime dedi sen nerden emeklisin. Ben 
malulen emekliyim dedim. Yok, ben seni alamam sen baylIırsın ondan sonra ben seninle ne yapıcam dedi." (47, erkek, daha önce çalışmış, evli)

"Almıyorlar İ̧̧kur(Türkiye İş Kurumu)'a gidiyoruz almıyorlar bizi mesela. Şey yapıyorlar raporumuza bakıyorlar diyorlar sen git sonra gel. 10 kere oldu böyle ben de gitmiyorum artık İşur'a ne gidicem yine aynı olay olacak. Almıyorlar yani işte çok önyargılar var. Şirketler sıkıntı yaratıyor. Almıyorlar diyorlar başımıza bela olur, saldırganlar bunlar, daha kötü olacak, başımıza bir iş açar böyle tuhaf tuhaf düşünceler taşıyorlar." (34, erkek, daha önce çalışmış, bekâr)

\section{Maaşın kesilmesi}

Bireysel derinlemesine görüşme yapılan bireylerin büyük çoğunluğu engellilik maaşın kesilmesinin çalışamama nedenlerinden biri olduğunu belirlenmiştir. Bireyler genellikle çalışmak istediklerinde engellilik maaşlarının kesildiğini ve kesilen maaşı tekrar bağlatmanın da uzun zaman aldığını bu yüzden bir işe girmeye cesaret edemediklerini ifade etmişlerdir. Aşağıda bu konuda bireylerin bazı ifadeleri yer almaktadır:

"Çalışamam çünkü çalıştığım zaman maaşıma el koyarlar." (51, erkek, daha önce çalışmış, bekâr)

"Şöyle bir şey var ben çalıştığım zaman sigortalı gösterilirsem maaşıma devlet el koyuyor. O yüzden çalışmıyorum. " (47, erkek, daha önce çalışmış, evli)

Damgalanma nedeniyle çalışma hayatında yaşanan güçlükler

Bireysel derinlemesine görüşme yapılan bireyler, damgalanma nedeniyle çalışma hayatında yaşanan güçlüklerin çalışamama nedeni olduğunu bildirmişlerdir. Bazı bireyler çalışma arkadaşlarının onlarla konuşmak istemediğini ifade ederken bazıları ise onlarla alay edildiğini, onlara "deli"ya da "çürük elma" denildiğini ifade etmişlerdir. Aşağıda bu konuya örnek olarak bazı katılımcıların ifadeleri bulunmaktadır:

"Orda bir çocuk benimle uğraşmaya başladı, konuşmuyorum içime kapanığım diye. O da konuşmak istiyordu ben konuşmuyordum. O yüzden benimle uğraşmaya başladı. Rahatsız olduğumu anladı biraz. Benimle uğraşıp durunca ben de bırakıp çıktım. Alay ediyordu. Alay değil de iğneli iğneli laflar söylüyordu benim obsesyonlarımla ilgili. Hareketleriyle filan bana yansıtmaya çalışıordu. Aynısını taklit ediyordu." (47, erkek, daha önce çalışmış, bekâr)

"Ben çalışırken oradakiler bana gülüyordu. Mesela servis şoförü normal bildiğin servisin şoförü geliyor sana diyor ki bu çürük elmaları da nereye bırakıcaz diyor laf atıyor özürlülere. Düşün yani özürlülere çürük elmalar diyor." (34, erkek, daha önce çalışmış, bekâr)

\section{Çalışmanın hasta üzerine etkileri}

Bireysel derinlemesineler sonucu ile ortaya çıkan güçlü temalardan bir diğeri de çalışma hayatının hasta üzerindeki etkileridir. Çalışmanın hasta üzerine etkilerinde katılımcıIarın, çalışmanın olumlu etkileri ve çalışmamanın olumsuz etkileri olmak üzere 2 farklı görüş üzerine odaklandıkları görülmektedir.

\section{Çalıșmanın olumlu etkileri}

Araştırmaya katılan bireylerin bir kısmı çalışmanın onlara olumlu etkilerinden, onlara nasıl hissettirdiğinden ve çalışan insanları gördüklerinde neler düşündüklerinden bahsetmiştir. Bireyler çalışan insanların maddi ve manevi açıdan daha şanslı olduğunu, bir işte çalışmanın insana iyi hissettirdiğini hatta ilaç gibi geldiğini söylemişlerdir. Aşağıda katılımcıların bu konu hakkındaki ifadelerinden bazılarına yer verilmiştir:

"Şanslı olduklarını hissediyorum. Maddi açıdan destek görüyorlar para kazanıyorlar. Biraz daha psikolojileri iyi biraz daha şanslılar." (34, erkek, daha önce çalışmış, bekâr)

"Kız arkadaşlarım vardı, birbirimize hep şarkılar gönderiyorduk. Yemek paydosunda aralarda sohbetler ediyorduk. Bazen biz onların evine gidiyorduk, onlar bize geliyorlardı, iyiydi." (26, kadın, daha önce çalışmış, bekâr)

\section{Çalışamamanın olumsuz etkileri}

Araştırmaya katılan bireyler, çalışamamanın olumsuz etkileri üzerinde de durmuşlardır. Bireyler çalışmadıkları zaman maaş alamadıklarını, maddi açıdan zorlandıklarını, sosyalleşemediklerini ve bir uğraşları olmayınca sıkıldıklarını söylemişlerdir. Aşağıda bu konuda bir bireyin ifadesi yer almaktadır:

"Para kazanmak çok zor bizim için. Durumumuz iyi değil yani sosyal olabilmek için para lazım bir sürü şey lazım yani. Üzülüyoruz yani çalışmadığımız için maddi açıdan zorlanıyoruz. Sosyal olamıyoruz. Her şey para değil ama bu hastalıkta para çok önemli bir faktör." (34, erkek, daha önce çalışmış, bekâr)

\section{Çözüm önerileri}

Bireysel derinlemesine görüşme yöntemi ile yapılan görüşmelerden elde edilen bilgiler ışığında ortaya çıkan bir 
diğer tema ise çözüm önerileridir. Ana temalardan sonuncusu olan çözüm önerileri 4 alt temadan oluşmaktadır. Bunlar; hastalığa uygun işler, halkın eğitimi, derneklerin arttırılması ve devletle ilgili çözümlerdir.

\section{Hastalığa uygun işler}

Araştırmaya katılan bireylerden bazıları hastaların çalışabilmesi için onlara uygun işler ayarlanması gerektiğinden bahsetmişlerdir. Bireyler uzun çalışma saati olan işlerin onları çok zorladığından, kısa zamanlı işlerde daha rahat çalışabileceklerini ifade etmişlerdir. Aşağıda katılımcıların bu konu hakkındaki ifadelerinden bazılarına yer verilmiştir:

"Bizim için böyle şey lazım, kasiyerlik, garsonluk gibi. Bu tarz yerler açılsa belki çalışabiliriz, günlük olarak." (41, erkek, daha önce çalışmış, evli)

"Şizofrenlere yani bir 6-7-8 saatlik iş olması lazım 15-16 saatte çok zorlanıyoruz." (34, erkek, daha önce çalışmış, bekâr)

\section{Halkın eğitimi}

Yapılan bu çalışma sonucunda hastaların bir kısmı damgalanmanın önüne geçebilmek adına çözüm önerisi olarak halkın hastalık hakkında bilinçlendirilmesi gerektiğini savunmuştur. Bireyler halkın konu hakkında bilinçli olmadığından hastalıklarını gizlediklerini, çözüm olarak da halkın uzman kişiler tarafından seminerler, paneller düzenlenerek bilinçlendirilmesi gerektiğinden bahsetmişlerdir. Katılımcıların bu konu hakkındaki ifadeleri aşağıda yer almaktadır:

"Yani insanların bilgilendirilmesi gerekiyor, tıbbi olarak bir hastalık durumu var, bu herkeste olabilir, beyinde olabiliyor. Bilinçlendirmek gerekiyor." (53, erkek, daha önce çalışmış, bekâr)

"Topluma saldırgan değil diyeceğiz. Seminer olur, panel olur. Psikologlar da destek verir." (41, erkek, daha önce çaIışmış, evli)

\section{Derneklerin arttırılması}

Araştırmaya katılan bireylerin, şizofreni hastaları için kurulmuş olan derneklerin sayısının arttırılması gerektiğini düşündükleri saptanmıştır. Aşağıda katılımcıların bu konu hakkındaki ifadelerinden bazılarına yer verilmiştir:

"Böyle merkezlerin artırılması, aktivitelerin artırılması, meşguliyet, kitap okuma bunlar." (47, erkek, daha önce çalışmış, bekâr)
Devletle ilgili çözümler

Bireysel derinlemesine görüşme yapılan bireyler, iş hayatında yaşanan güçlükler için devlet tarafından engelli kontenjanının artırılması, özel sektöre de bu kontenjanla ilgili yük getirilmesi, iş yerlerinin yeterli sayıda engelli birey çalıştırıp çalıştırmadığı konusunda gerekli denetimlerin yapılması, ruhsal hastalar için korumalı iş yerlerinin açılması gibi çözümler getirilmesinin gerekliliğinden bahsetmişlerdir. Aşağıda bireylerin bu konudaki düşüncelerini belirttikleri ifadeler yer almaktadır:

"Devletten engelliler için daha fazla kontenjan istiyorum ben. Bilinçlendirmek, özel sektöre de yük getirmek gerek. Benim bildiğim kadarılla bazı özel sektörde bazı is yerleri \%3 kontenjan ayırıyorlar. 100 kişiden 3 kişiyi engelli olarak çalıştırma zorunluluğu var. Onu yaygınlaştırmak gerekiyor. 100de 3 olacağına 10da 3 olabilir." (47, erkek, daha önce çalışmış, bekâr)

"Korumalı iş yerleri yapılabilir bizim için İzmit'te var mesela bir tane. Üreten engelliler topluma kazandırılıyor. Devletin \%3 engelli kontenjanı var mesela ama işveren engelliler için öyle şartlar istiyor ki Ingilizce bilsin yok şu özelliği olsun bu özelliği olsun sonra bize bu şartlarda çalışan başvurmadı o yüzden çalıştıramıyoruz diyorlar. Bu konuda denetim eksikliği var denetimin düzenli yapılması lazım." (51, erkek, daha önce çalışmış, bekâr)

\section{Tartışma}

Bu araştırmanın amacı şizofreni hastalarının iş hayatında hangi sorunlarla karşılaştıklarını ve bu sorunlara yönelikçözüm önerilerinin neler olduğunu belirlemektir. Araştırma sonucunda hastaların iş hayatında yaşadıkları güçlüklerin 1) çalışmama nedenleri, 2) çalışmanın hasta üzerine etkileri ve 3) çözüm temalarını içerdiği belirlenmiştir.

Araştırmanın ilk ve en önemli teması çalışmama nedenleri olarak belirlenmiştir. Katılımcılar, hastalığın etkisinin, öncelikle fiziksel güçlerini buna bağlı olarak da çalışma hayatlarını etkileyen önemli bir faktör olduğunu ifade etmişlerdir. Sağlık durumunun iyi düzeyde olmasının bireylerin çalışmaya daha istekli ve hevesli olmalarını, kendilerinde çalışma gücü bulmalarını etkilediğini ifade etmişlerdir. Yılmaz'ın (2012) şizofreni hastalarıyla yaptığı bir çalışmada hastaların çalışma durumuna baktığında \%73'ünün çalışmadığını ve hastalık nedeniyle işten çıkma durumunu incelediğinde ise çalışmaya katılanların büyük çoğunluğunun $(\% 61,5)$ hastalık sebebiyle işten çıktığını ifade ettiklerini belirlemiştir (10). Kalitatif olarak yapılan başka bir çalışmada ise şizofreni hastası olan bir katılımcıya işte 
kalmasını etkileyen en önemli faktörün ne olduğu sorulduğunda bireyin, az ya da çok sağlıklı olmak dediği görülmüştür. Yine aynı çalışmada belirtilerin şiddetinin ve nüks görülme sıklığının istihdam edilme ve işte kalma ile ilişkili olduğu ifade edilmiştir (11). Yapılan bu çalışmada katılımcıların çalışmama nedenlerinden biri olan hastalığın etkisi bu konuda kısıtlı yapılan çalışmalara bakıldığında literatür ile uyumludur. Bu konuda ülkemizde ve hatta dünyada bu türde yapılan çalışma sayısının azlığı göz önünde bulundurulduğunda şizofreni hastalarının çalışmama nedenleri, hastalığın bu duruma neler kattığı konusunda araştırmalar yapılmasına ihtiyaç olduğu görülmüştür.

Çalışmama nedenlerinden hastalığın etkisi kadar önemli olan bir diğer faktör ise hastaların işe alınmamalarıdır. Katılımcılar işverenlere şizofreni tanıları olduklarını söylediklerinde şizofreni tanısı alan hastaların saldırgan olarak görüldükleri için işverenler tarafından işe alınmadıklarından, onlara karşı çok önyargılı olunduğundan bahsetmişlerdir. Birleşmiş Milletler Engelli Hakları Sözleşmesi'ne (2006) göre ülkemizin de dâhil olduğu taraf devletler engellilerin diğer bireylerle eşit çalışma hakkına sahip olduğunu kabul etmektedir. Bu sözleşmede taraf devletlerin "engelli kişilerin kamu sektöründe istihdam edilmesi, engelli kişiler için işgücü piyasasında istihdam firsatları ve işte ilerleme imkânlarının teşvik edilmesi ve ayrıca iş bulma, işte çalışma ve işe dönme konusunda yardım sağlanması, işyerinde engelli kişiler için makul imkânların bulunmasının sağlanması, engelli kişilerin, genel teknik ve mesleki yönlendirme programları, işe yerleştirme hizmetleri ve mesleki ve sürekli eğitimden etkin şekilde yararlanabilmeleri" gibi amaçlarının olması gerektiği açıkça yazmaktadır (12). Ülkemizde bir işe girmek için pozitif ayrımcılıktan yararlanmak isteyen engelli vatandaşlarımız Türkiye İş Kurumu'na (IŞKUR) başvurabilmektedirler. Ancak bu uygulamanın en büyük problemi işverenlere engelli bireylerin engel türleri arasından seçim yapma imkânı veriyor olmasıdır. Ruhsal hastalığı olan bireylere yapılan damgalama diğer engellilere yapılandan daha şiddetli olduğu için işverenler de psikiyatrik bir hastadan çok diğer engellileri işe almayı tercih edebilirler (13). Yapılan araştırmalara bakıldığında ise şizofreni hastalarının büyük çoğunluğunun çalışmadığı görülmekte ancak bunun işverenden mi yoksa hastadan mı kaynaklandığına dair detaylı bir araştırma örneği bulunmamaktadır (14.15.16). Bizim yaptığımız çalışmaya baktığımızda ise hastaların tümünün şizofreni tanısı aldıkları için işe alınmadıkları konusunda fikir birliği olduğu görülmüştür. Konu hakkında detaylı çalışma örneklerinin bulunmaması nedeniyle araştırmacıların bu konuda daha detaylı araştırmalar yapmalarına intiyaç doğmuştur.
Araştırma bulgularına göre çalışmama nedenlerinin bir diğer önemli faktörü ise; şizofreni hastalarının bir işe girdiklerinde almış oldukları engelli maaşının kesiliyor olmasıdır. Çalışmaya katılan şizofreni hastaları malullük raporu sonucunda kendilerine maaş bağlandığını, ancak bir işte çalışmaya başladıkları takdirde, sigortalarının tekrar başlaması durumunda aldıkları engelli maaşının kesileceğini ve maaşın kesilmesini istemedikleri için de çalışmadıklarını ifade etmişlerdir. Şizofreni tanılı hastalarının \%80 çalışma gücü kaybı olduğu durumda bireyler raporlanmaktadır. Ekonomik yoksunluğu da bulunan kişiler 2022 sayılı kanun gereği engelli maaşına bağlanır (17). Ülkemizde engelli bireylere verilen sosyal desteklerin birey bir işe başladığında son bulmasından dolayı ve ruhsal bozukluğu olan birey tekrar alevlenme dönemine girip işini de kaybetme kaygısı yaşadığından dolayı, engelli maaşını reddedip, işe girmeye cesaret edememektedirler (18). Literatür sonuçlarına bakıldığında da engelli maaşı alan kişiler bu maaşı belirli şartlar doğrultusunda almaktadırlar. Herhangi bir işte çalışmaya başladıklarında ise yapılan gelir araştırmaları sonucunda aldıkları engelli maaşından men edilmektedirler. Bu sebeple şizofreni hastaları işe başladığında, üretkenliklerinin ortaya çıkması açııından, aldıkları sosyal desteklerin kesilmemesinin daha doğru olacağı öngörülmektedir.

\section{Damgalanma nedeniyle çalışma hayatında yaşanan} güçlüklerin, şizofreni hastalarının çalışmama nedenlerinin bir diğer komponenti olduğu belirlenmiştir. Yapılan araştırmada, katılımcılar iş hayatında ikinci sınıf muameleye maruz kaldıklarını, kendilerine karşı ön yargılı olunduğunu ve diğer bireyler tarafından saldırgan olarak görüldüklerini ifade etmişlerdir. İnsanların akıllarında beliren şizofreni algısının genellikle olumsuz olduğunu söylemişlerdir. Araştırmaya katılan bireylerin iş hayatında damgalanmamak için hasta rolünü reddettikleri, saklama yoluna gittikleri görülmektedir. Sağduyu ve arkadaşlarının (2001) Türkiye'de yapmış olduğu epidemiyolojik bir çalışmada katılımcıların \%46,8'inin şizofreni hastasıyla birlikte çalışmayacağını belirttiğini, ayrıca şizofreni hastalarının saldırgan olduğuna inananların oranının ise $\% 27,3$ olduğunu saptamışlardır (19). Yapılan diğer çalışmalara bakıldığında ise şizofreni hastalarının saldırgan ve ortamdaki diğer kişiler için tehlike oluşturabilecek kişiler olarak görüldükleri, iş görmez olarak değerlendirilip çalışma hayatlarına devam etmelerinde engel oluşturduğu belirtilmiştir $(4,20)$. Yapılan çalışmalar ve bizim bulduğumuz sonuçlara baktığımızda ülkemizde şizofreni hastalarına karşı ciddi önyargıların olduğu görülmüştür. Toplumun bu önyargılarının yıkılması için halkın şizofreni hastalığı hakkında psikiyatri hemşireleri tarafından bilinçlendirilmesinin uygun olacağı düşünülmektedir. 
Araştırmanın diğer bir teması ise çalışmanın hasta üzerine etkileri olarak belirlenmiştir. Bireyler özellikle çalışmanın olumlu etkileri ve çalışmamanın olumsuz etkileri üzerinde durmuşlardır. Araştırmaya katılan katılımcılar özellikle çalışmanın hasta üzerine olumlu etkileri olduğunu düşünmektedirler. Katılımcılar çalıştıkları zaman maddi açıdan destek görebildikleri, psikolojilerinin daha iyi olduğu, stres attıkları, arkadaş edinebildikleri gibi olumlu etkiler üzerinde durmuşlardır. Bir işte çalışmak hastaya yalnızca maddi bir kaynak değil aynı zamanda onun içinde bulunduğu psikiyatrik durumunun düzelmesine de yardımcı bir araçtır. Taskila ve arkadaşlarının (2014) şizofreniyle çalışma hakkında uzmanlarla yaptıkları kalitatif bir araştırmada katılımcılardan bazıları bir işte çalışmanın tedavinin bir parçası olduğundan, çalışmanın insanın hayatını bir düzene koyduğundan ve insanlara daha iyi hissettirdiğinden bahsetmiştir (21). Dunn ve arkadaşlarının (2008) yaptığı, katılımcıların çoğunluğunun şizofreni hastası olduğu kalitatif bir çalışmada araştırmaya katılan bireylerden bazılarının bir işte çalışmanın kişilerin benlik saygılarını geliştirdiği, kendilerine ihtiyaç duyulduğunu düşündüklerini ve kendilerini değerli hissetmelerini sağladığını söylemişlerdir. Hatta yaptıkları çalışmada bir işte çalışmanın bireylerin psikiyatrik engellilik durumlarıyla baş etmelerini sağladığını da ifade etmişlerdir (22). Aynı şekilde yapılan başka bir çalışmada da mali kaynağa sahip olarak ve toplumsal bir rol üstlenerek çalışmanın bireylerde yüksek benlik saygısını geliştirdiğinden ve şiddetli semptomların daha az sıklıkta görüldüğünden bahsedilmiştir (23). Bizim çalışmamızdaki sonuçlara baktığımızda ise bulguların literatür ile uyumlu olduğu görülmüştür. Bu nedenle ruhsal bozukluğa sahip hastaların iyileşebilmelerine katkı sağlamak için onları dışlamak yerine onlara bir şans vermenin daha uygun olacağı göz önünde bulundurulmalıdır.

Katılımcılar, çalışmanın hasta üzerindeki etkilerinden bahsederken çalışmamanın olumsuz etkileri üzerinde de durmuşlardır. Araştırmaya katılan bireyler çalışma hayatı sayesinde bir uğraşı alanlarının olduğunu, ancak çalışmadıkları takdirde sosyal yaşamlarının olumsuz etkilendiğini, maddi olarak zorlandıklarını belirtmişlerdir. İşsizlik, kişide işe yaramama, verimsizlik hislerine neden olmaktadır (20). Ülkemizde ve yurt dışında yapılan çalışmalarda, çalışmayan bireylerin benlik saygılarında, öz yeterliliklerinde azalmaların olduğuna dikkat çekilmiştir. İşsizliğin, tüm bireyleri parasal ve psikolojik sıkıntıya sürüklediği bilinmektedir, ayrıca işsizlik ile parasal ve psikolojik sıkıntı arasındaki ilişki apaçık ortadadır (24). Yapılan diğer bir çalışmaya bakıldığında herhangi bir işte çalışmayan şizofreni hastalarının hastalıklarının kötü seyrettiği, psikolojilerinin olumsuz etkilendiği açıkça belirtilmiştir (25). Bu bağlamda, çalışmıyor olmanın aslında her birey için olumsuz etkiler doğurduğu ortaya konmuştur.

Araştırmanın son ve bir diğer önemli teması ise çözüm temasıdır. Katılımcıların iş hayatında yaşadıkları güçlükleri minimuma indirgemek için ifade ettikleri en önemli çözüm önerilerinden biri hastalığa uygun işler bulunmasıdır. Bireyler normal bir işçi gibi uzun saatler çalışmanın onları çok yorduğunu ve ağır geldiğini, 7-8 saatlik işlerin ise fiziksel ve psikolojik açıdan onlara daha uygun olacağını ifade etmişlerdir. Taskila ve arkadaşlarının (2014) akademik psikiyatr, klinik psikiyatr, işveren, istihdam destek uzmanları, konsültasyon hemşiresi gibi uzmanlarla yaptığı bir çalışmada bazı işverenler ve istihdam destek uzmanları her şizofreni tanısı alan hastanın aynı olmadığını hatta hepsinin birbirinden farklı olduğunu, sahip oldukları beceriler de farklı olduğundan onların yeteneklerini ve sahip oldukları tecrübeyi göz önünde bulundurmak gerektiğini ifade etmişlerdir (21). Sağlık Bakanlığı Ulusal Ruh Sağlığı Eylem Planı'na (2011-2023) göre ise ülkemizde ağır ruhsal hastalığı olanlar 2 şekilde istihdam edilmektedir. Bunlardan birincisi yarışmalı işler ikincisi ise korumalı işyerleridir. Yarışmalı işler herkesin başvurup çalıştığı işlerken korumalı işyerleri ise özerk çalışma kuralları olan hastaların gelir elde edebildikleri yerlerdir. Özellikle ülkemizde korumalı işyeri henüz yaygınlaşmadığından ruhsal hastalığı bulunan bireyler İşkur'a (Türkiye İş Kurumu) başvurarak onlara uygun iş bulunmasıyla çalışma hayatına girebilmektedirler (18). İşkur'un 2008 (Eylül) verilerine göre ruh hastalığı grubundaki bireylerin 7728 tanesinin başvuru yaptığı ancak sadece 650 tanesinin bir işe yerleştirildiği görülmüştür (26). 2012 Temmuz ayı verilerine göre ruhsal problemi olan bireylerin 5544'ü İşkur'a kayıtlıdır. 2010 yılında 1303, 2011 yılında 1495 ve 2012 yılında yalnızca 710 ruhsal hastalığı olan birey işKUR tarafından bir işe yerleştirilmiştir (13). Verilere baktığımızda hem İşkur'a başvuran ruhsal bozukluğu olan birey sayısı hem de işe yerleştirilen birey sayısı yıllar içinde düşmektedir.??? Düşmek mi? Bunun bireylerin bir işe başladığında engelli maaşlarının kesilmesi ve işten çıktıklarında tekrar bu maaşı bağlatmanın uzun zaman almasından kaynaklanabileceği düşünülmektedir. Norveç'te 1998-2002 eylem planı sonucunda işveren kooperatifleri zihinsel engelli ve psikiyatrik hastalar için daimi işyerleri açmışlar ve istihdamlarını sağlamışlardır (27). Buna rağmen yapılan başka bir çalışmada, 2006 yılında Norveç'te kategorilere ayrılan engelliler (görme, işitme, uzuv kaybı olan vs.) arasında mental rahatsızlığı olanların \%27.5 istihdam oranı ile engelliler arasında ruh hastalarının en düşük çalışma oranına sahip oldukları görülmüştür (28). Ayrıca hastalığa uygun iş denildiğinde 
yalnızca bireyin kapasitesi, yetenekleri ve o işi yapıp yapamayacağı değil onun alevlenme dönemlerinde iş devamsızlıklarını da tolere edebilecek işler akla gelmelidir. Çünkü hastaların hastalıklarından dolayı iş devamsızlıkları ve işten ayrılma isteği artmaktadır. Türkiye Ruh Sağlığı Profili Raporu'na (1998) göre ruhsal hastalık sebebiyle iş devamsızlığı 1 hafta veya daha uzun süreli olmaktadır. Ancak bu bireylerden çalışması uygun bulunanlar iş hayatına kazandırılmalı ve hakları da yasalarla güvence altına alınmalıdır (26). Literatüre baktığımızda şizofreni ile ilgili özelleşmiş çalışmalar bulunmamasına rağmen İşkur verilerine göre yaptığımız çalışmanın sonuçlarının verilerle uyumlu olduğu görülmektedir.

Katılımcıların iş hayatında yaşadıkları güçlükleri azaltmak amacıyla önerdikleri bir diğer çözüm yöntemi ise halkın eğitimidir. Araştırmaya katılan bireyler şizofreninin de diğer hastalıklar gibi bir hastalık olduğunu, toplumun bu konuda bilinçlendirilmesi gerektiğini bunun için de seminerler, paneller ya da televizyon aracılığıyla bir takım şeyler yapılabileceğini ifade etmişlerdir. Ülkemizde psikiyatri ile ilgili yapılan neredeyse tüm çalışmalarda toplum tarafından ruhsal hastalığı olan bireylere karşı bir damgalama yapıldığı görülmektedir $(10,29,30)$. Araştırmacılar da yaptıkları çalışmalar sonucunda karşılaştıkları ruhsal hastalıkları ve hastaları damgalamaya karşı bazı önerilerde bulunmuşlardır. Doğanavşargil (2009) şizofreni hastalarıyla ilgili yaptığı bir çalışmada damgalamanın önüne geçebilmek için öncelikle ruhsal hastalıklarla ilgili yanlış bilgi, tutum ve düşüncelerin değiştirilmesi için bir ruh sağlığı politikasının olması gerektiğini söylemiştir. Ayrıca tüm sağlık basamaklarındaki hekimlerin konuyla ilgili eğitilmeleri ve psikiyatristlerin toplumun önüne daha çok çıkıp halkı bilinçlendirmeleri gerektiğini ifade etmiştir (7). Özçelik (2015) ise şizofrenilerle yaptığı bir çalışmanın sonucunda damgalamaya karşı ruhsal hastalıklarla ilgili kalıplaşmış toplum ifadelerine, medyada çıkan haberlere karşı çıkılmasını, kitap, kamu spotu, yapılandırılmış öğretim programı gibi yöntemlerle yanlış bilgi, fikir, söylentiler konusunda eğitimler yapılmasını önermiştir. Bunun dışında toplum temelli eğitim, akran destek grupları gibi faaliyetler yapılabileceğini söylemiştir (9). Ruhsal hastalıklara karşı damgalamayla ilgili yapılan bir çalışmada da eğitimle toplumda davranış değişikliğinin oluşturulmasını, tıp ve hemşirelik eğitiminin gözden geçirilerek psikiyatri eğitim programına bilgi, inanç ve tutum değişikliği sağlayacak özel eğitim programlarının eklenmesini, öğretmen, din adamı, basın mensubu, muhtar, sağlık personeli, polis gibi toplumun önderleri konumundaki meslek gruplarının damgalama ile mücadele hakkında eğitilmelerini ifade etmiştir (31). Çalışmamızda hastalarla yapılan görüşmelerde hastaların önerdikleri çözüm yöntemleri ile literatürde yapılan çalışmaların sonucunda önerilen çözümler birbiri ile uyum sağlamaktadır. Bütün bunlar göz önünde bulundurulduğunda şizofreni hastalarına karşı damgalamayı azaltacak en güçlü faktörün toplumun bilinçlendirilmesi olduğu açıkça görülmektedir.

Katıımcıların iş hayatında yaşadıkları güçlükler için ifade ettikleri bir diğer çözüm önerisi ise derneklerin arttırılması gerektiğini ifade etmişlerdir. Şizofreni dernekleri sayesinde bir araya geldiklerini, sorunlarını paylaştıklarını, aktiviteler düzenleyerek bu kuruluşların hastaların sosyalleşmesi için önemli ortamlar olduğunu bildirmişlerdir. Resim ve müzik çalışmaları yürüttükleri, takı tasarımı yaptıkları, rahatça kitap okuyabildikleri bu merkezlerin fazla sayıda olmasını istediklerini ifade etmişlerdir. Uğurlu (2011) şizofreni hastalarıyla yapmış olduğu çalışmasında, hasta ve yakınlarının katılımıyla kurulmuş olan bu tip derneklerde, onların arkadaşlar edinip, işlevsellik kazandıkla$\mathrm{rl}$, duygusal olarak birbirlerine destek oldukları görülmektedir. Şizofreni derneklerinde hastalar ve ailelerin bir araya gelerek sahip oldukları ve istedikleri haklar için savunuculuk yaptıklarını belirtmiştir (4). Hastaların derneklerin dışında tedavi sonrası gidebileceği hem tedavilerinin takip edildiği hem de çeşitli aktiviteler yapabildikleri yerlerden biri de Toplum Ruh Sağlığı Merkezleri (TRSM)'dir (32). Bilge ve arkadaşlarının yapmış olduğu bir çalışmada ülkemizde ilk TRSM sonrası bugüne kadar toplam 106 TRSM açılmıştır (33). Şizofreni hastalarının hem sosyalleşmesine hem de işlevselliklerini sürdürmesine yardımcı olan böyle derneklerin ve TRSM'lerin arttırılmasının ve hastaların buraya yönlendirilmesinin uygun olacağı düşünülmektedir.

Araştırmaya katılan katılımcılar, devletle ilgili çözümlerin de genişletilmesi gerektiğini bildirmişlerdir. Katılımcılar devletin engelli bireylerin çalışabilmesi için açtı̆̆ı \%3'lük engelli kontenjanının yeterli olmadığını, arttırılması gerektiğini ifade etmişlerdir. Bin dokuz yüz yetmiş bir tarihinden beri, Özürlüler Yasası'nda belirtildiği üzere, kamu kurum kuruluşlarındaki çalışanların asgari \%3'ünün engelli bireylerden oluşması gerektiği bildirilmiştir. Bu istihdamdan yararlanabilecek olan engelli bireylerin işKUR'a başvuru yapmaları beklenir. Sonrasında IŞKUR, bireyleri engelliler için ayrılmış olan kontenjandaki işlere yönlendirmektedir. Ancak, işKUR bu bireyleri sadece engelli vatandaşlar için ayrılmış olan işlere aktarır, bireyler öğrenim durumları doğrultusunda uygun işlere yerleştirilememiş olur. Bu kontenjan tüm engelli bireyleri kapsadığı için de, işverenlerin ruhsal engelli kişileri işe almak yerine, genellikle diğer engeli bulunan kişileri işe almayı tercih ettikleri bilinmektedir. Yüzde üçlük olan kontenjanın ne kadarlık 
kısmının ruhsal engelli bireylere ayrıldığının yasal olarak belirlenmesi gerekmekte ya da ruhsal engeli olan bireylere ayrımcılık yapılmasının hukuki olarak yasaklanmasıyla ruhsal engeli olan bireylerin istihdamında ortaya çıkan engeller yok edilebilir $(13,39)$. Ayrıca, hastalar ülkemizde korumalı iş yerlerinin de olmasının gerekliliğinden bahsetmişlerdir. Katılımcılar korumacı şekilde yaklaşım görmek istediklerini ve rahat bir çalışma ortamı istediklerini ifade etmişlerdir. Hastalar istihdam edilmede pek çok zorlukla karşılaşmaktadırlar. Büyük çaplı olan işletmelerin engelli çalıştırmak zorunda tutulup, aksi halde ceza şeklinde yaptırıma tutulacağı bilinmektedir. Engelli bir bireyi bir işte çalıştırmak için belirli bir kadro sınırı getirilmiş olsa da, pek çok problemlerden dolayı engelli istihdam sayısında artış görülememektedir $(34,35)$. Korumalı iş yerleri ise çalışma yaşamına atılamayan, iş bulamayan engelli bireyler için istihdam alanı sağlamaktadır. Bunun için devlet tarafından mali ve teknik olarak çalışma ortamı düzenlenir. Devlet, bireyler için bu iş imkanını sağlarken aynı zamanda da rehabilitasyon, eğitim ve sosyal alanda da desteklemekte$\operatorname{dir}(36,37,38)$. Korumalı iş yeri sistemi Türkiye'de de uygulanmaya başlanmıştır. Türkiye'deki hukuk sistemine göre bireylerin hem psikiyatrik hasta teşhisi almış olması hem de sağlık kurul raporlarında özürlülük oranlarının $\% 40$ 'tan fazla olması gerekmektedir (13). İtalya'da ise ruh sağlığı merkezlerinin içine ruhsal sorunu olan hastaların istihdamı için sosyal kooperatifler kurulmuştur. Ruh sağlığı merkezleri bu kooperatiflerle ortak çalışarak korumalı işyerleri açmakta ve ruhsal problemi olan kişilerin haftada 20 saati aşmayacak şekilde çalışması sağlanmaktadır. Elde edilen kar ise çalışanlar ve işletmeciler arasında paylaştırılmaktadır (13). Ruhsal problem yaşayan bireylerin çoğunda zekâ ile ilgili problem bulunmamaktadır ve bu bireylerin uygun iş imkânı sağlandığı takdirde çalışabildikleri belirtilmiştir (13). Tüm bunlar göz önünde bulundurulduğunda;

\section{Kaynaklar}

1. Ekinci M, Kavak, F. Kendi Evlerinde Yaşayan ve Korumalı Evlerde Yaşayan Şizofreni Hastalarının Yaşam Niteliklerinin ve İ̧̧levsel İyileşme Düzeylerinin Karşılaştııılması. Gümüşhane Üniversitesi Sağlık Bilimleri Derg 2014; 3: 588-98.

2. Öztürk S. Şizofreni Hastalarında Yaşam Kalitesinin; Pozitif Belirtiler, Negatif Belirtiler, Depresyon ve İçörü ile İlişkisi. Tıpta Uzmanlık, Bülent Ecevit Üniversitesi, Zonguldak, 2010.

3. Yavuz R. Şizofreni. İstanbul Üniversitesi Cerrahpaşa Tıp Fakültesi Sürekli Tıp Eğitimi Etkinlikleri, Sempozyum Dizisi 2008; 62: 49-58.

4. Uğurlu N. Şizofreni Tanısı Konan Hastalarda Bir İşte Çalışmanın ve Derneğe Üye Olmanın İşlevsel İyileşme, Tedaviye Uyum ve Stresli Durumlarla Baş Etme Üzerine Etkisi. Yüksek Lisans, Gazi Üniversitesi, Ankara, 2010.

5. Akmeşe ZB, Bilge A, Çakır N, Çam M.O, Engin E, Turgut E.Ö. Muhtarlara Verilen Ruhsal Hastalığa Yönelik Damgalama ile Mücadele Eğitiminin Etkililiğinin Araştırılması. Psikiyatri Hemşireliği Derg 2014;5:129-36. [CrossRef] ülkemizdeki korumalı iş yerlerinin sayısını arttırarak, ruhsal engelli bireylerin istihdam alanında sayılarının arttırımış olacağı ve istihdam alanında devam etme sürelerinin de aslında artmasının sağlanmış olacağı, \%3'lük kontenjanın ise artırılabileceği ya da kontenjanın ruhsal engelliler için belirli bir kısmının hukuki olarak sınırlandırılması gerektiği açıç̧a görülmektedir.

\section{Sonuç}

Şizofreni hastalarının iş hayatında yaşadıkları güçlükleri belirlemek amacıyla yapılan bu araştırmada, şizofreni hastalarına karşı tutum ve iş hayatında damgalamaya yönelik olumsuz sonuçların olduğu belirlenmiştir. Bu araştırmanın sonuçları, şizofreni hastalarının iş bulma ve iş hayatında yaşadıkları güçlüklerin varlığını desteklemektedir. Şizofreni hastalığının, şizofreni tanısı alan bireylerin çalışma hayatını etkilediği, şizofreni tanısı alan bireylerin işverenler tarafından kabul edilmediği ya da engelli maaşı alan bireylerin maaşının kesileceği gibi nedenlerle iş hayatında yer alamadıkları araştırmamızda açıkça görülmektedir. Bu sebeple hastaların damgalanmasının önlenmesi ve iş hayatında yer alabilmeleri amacıyla psikiyatristlerin ve psikiyatri hemşirelerinin bu konuda daha ön planda olmaIarının, halkı bilinçlendirme çalışmaları yapmalarının etkili olabileceği düşünülmektedir. Ayrıca işverenlerin ve engeli olmayan bireylerin bu konu hakkındaki düşünceleriyle ilgili de çalışmalar yapılmasının önemli olduğu düşünülmektedir. Sağlık Bakanlığı'nın şizofreni hakkında bilinçlendirici kamu spotu reklamları yapmasının damgalamayı azaltacağı öngörülmektedir. Devlet politikalarında da bu konuya yer verilerek işverenlerin alacağı \%3'lük engelli personel kontenjanında şizofreni hastalarına da zorunlu yer verilmesi, hastaların topluma katılması açısından uygun olacaktır.

6. Saillard EK. Ruhsal Hastalara Yönelik Damgalamaya ilişkin Psikiyatrist Görüşleri ve Öneriler. Türk Psikiyatri Derg 2010; 21: 14-24.

7. Doğanavşargil Ö. Şizofreni ve Depresyonda İçselleştirilmiş Damgalanma ve Yaşam Kalitesi. Yüksek Lisans Tezi, Dokuz Eylül Üniversitesi, İzmir, 2009.

8. Gülseren L. Şizofreni ve Aile: Güçlükler, Yükler, Duygular, Gereksinimler. Türk Psikiyatri Derg 2002; 13: 143-51.

9. Özçelik EK. Şizofreni Hastalarında Aile Ortamı, İçselleştirilmiş Damgalanma ve Yaşam Kalitesi. Yüksek Lisans Tezi, Erzincan Üniversitesi, Erzincan, 2015.

10. Yılmaz E. Şizofreni Hastalarında İçselleştirilmiş Damgalanmanın Tedaviye Uyuma Etkisi. Yüksek Lisans Tezi, Ankara Üniversitesi, Ankara, 2012.

11. Steadman K. Working with Schizophrenia: Employment, Recovery and Inclusion in Germany. The Work Foundation Part of Lancaster University 2015; 23-4.

12. United Nations. United Nations Convention on the Rights of Persons with Disabilities 2006. http://www.un.org/esa/socdev/enable/ rights/convtexte.htm 
13. Yılmaz V. Insan Hakları ve Karşılaştırmalı Sosyal Politika Yaklaşımı Işığında Türkiye'de Ruh Sağlığı Politikaları: Tespitler ve Öneriler. İstanbul, Karika Matbaacılık, 2012.

14. Arslan M, Coşkun S, Kurt E, Yazıcı A, Yılmaz T. Rehabilitasyon Programının Şizofreni Hastalarının Kliniği, Sosyal İşlevselliği ve Yaşam Kalitesi Üzerindeki Uzun Dönem Etkileri: İzleme Çalışması. Anadolu Psikiyatri Dergisi 2015; 16: 238-46.

15. Emsley R, Filipcic IS, Grosic V, Pedisic I, Peles AM, Sagud M. Remission and Employment Status in Schizophrenis and Other Psychoses: OneYear Prospective Study in Croatian Patients Treated with Risperidone Long Acting İnjection. Psychiatria Danubina 2016;28: 263-72.

16. Eryıldız D. Gündüz Hastanesi ve Rehabilitasyon Merkezi'ne Devam Eden Kronik Şizofreni Hastaları ile Bir Rehabilitasyon Merkezine Katılmayan Kronik Şizofreni Hastalarının İşlevsellik ve Yaşam Kaliteleri Açısından Karşılaştırılması. Tıpta Uzmanlık, Bakırköy Prof. Dr. Mazhar Osman Ruh Saplığı ve Sinir Hastalıkları Eğitim ve Araştırma Hastanesi, İstanbul, 2008.

17. AilE VE SOSYAL POLITIKALAR BAKANLIĞI (ASPB). Engelli ve Yaşı। Bireylere İlişkin İstatistiki Bilgiler. Engelli ve Yaşlı Hizmetleri Genel Müdürlüğü 2017; 1-22.

18. T.C. Sağlık Bakanlığı. Ulusal Ruh Sağlığı Eylem Planı. Ankara, 2011-2023.

19. Aker T, Ögel K, Özmen E, Sağduyu A, Tamar D. Halkın Şizofreniye Bakışı ve Yaklaşımı Üzerine Bir Epidemiyolojik Araştırma. Türk Psikiyatri Derg 2001; 12: 99-110.

20. Yıldız M. Psikiyatrik Rehabilitasyon. Bireyden Topluma Ruh Sağlığı 2005; 1: 151-64.

21. Bevan S. Elston R. Gulliford J. Taskila, T. Thomas R. Steadman K. Working with Schizophrenia: Experts'Views on Barriers and Pathways to Employment and Job Retention. J Vocational Rehabilitation 2014; 41: 29-44. [CrossRef]

22. Dunn EC, Rogers ES, Wewiorski NJ. The Meaning and Importance of Employment to People in Recovery from Serious Mental illness: Results of a Qualitative. Psychiatric Rehabilitation J 2008;32:59-62. [CrossRef]

23. McGurk SR, Mueser KT, DeRosa TJ, Wolfe R. Work, Recovery and Comorbidity in Schizophrenia: A Randomized Controlled Trial of Cognitive Remediation. Schizophr Bull 2009; 35: 319-35. [CrossRef]

24. Çizel RB, Güzeller CO, Mütevellioğlu N. İşsizliğin Psikolojik Sonuçları: Antalya Örneği. Çalışma İlişkileri Derg 2011;2:26-41.
25. Ecide I, Hubschmid T, Priebe S, Warner R. Employment, Attitudes Toward Work, and Quality of Life Among People With Schizophrenia in Three Countries. Schizophr Bull 1998; 24: 469-77. [CrossRef]

26. Akarçay D. Türkiye'de Yürütülen Ruh Sağlığı Hizmetleri Politikalarının Değerlendirilmesi. Yüksek Lisans Tezi, Hacettepe Üniversitesi, Ankara, 2013.

27. Ataman H. Zihinsel Engelli ve Psikiyatrik Teşhis Almış Bireylerin İnsan Hakları. İnsan Hakları Gündemi Derneği ve Ruh Sağlığında İnsan Hakları İnisiyatifi, Ankara, 2008.

28. Knapp M, McDaid D, Medeiros H. Employment and Mental Health: Assessing the Economic Impact and the Case for Intervention. MHEEN Network 2008.

29. Akdede KBB. ve ark. Gençlerde Şizofreniyi Damgalama Düzeyi. Yeni Symposium 2004; 42: 113-7.

30. Küçük L. Oban G. Damgalama Erken Yaşlarda Başlar... Gençlerde Ruhsal Hastalıklara Yönelik Damgalamayla Mücadelede Eğitimin Rolü. Psikiyatri Hemşireliği Dergisi 2011; 2: 141-8.

31. Bilge A, Çam O. Ruhsal Hastalığı Yönelik Damgalama ile Mücadele. TAF Prev Med Bull 2010; 9: 71-8.

32. Alataş G, Arslan M, Karaoğlan A, Yanık M. Toplum Temelli Ruh Sağlığı Modeli ve Türkiye'de Toplum Ruh Sağlığı Merkezleri Projesi. Nöropsikiyatri Arşivi 2009; 46: 25-9.

33. Bilge A, Çam MO, Çetinkaya A, Erdoğan E, Mermer G, Üçkuyu N Türkiye'deki Toplum Ruh Sağlığı Merkezlerinin 2013-2015 Yıllarının Profili. Kocaeli Üniversitesi Sağlık Bilimleri Dergisi 2016; 2: 1-5.

34. Alpagut G. Korumalı İşyeri Kavramı ve Korumalı İş. Sicil İş Hukuku Dergisi 2006; 29-36.

35. Kuzgun İ. Türkiye'de Özürlülerin Ücret Karşılığı İstihdamını Belirleyen Değişkenler Ve Öneriler. Journal of Yaşar University 2014; 4:2451-66.

36. Arıkan Ç. Sosyal Model Çerçevesinde Engelliliğe Yaklaşım. Ufkun Ötesi Bilim Dergisi 2002; 2.

37. Çavuş ÖH, Tekin A. Türkiye'de Engellilerin İstihdam Yöntemi Olarak Korumalı İşyeri. Dokuz Eylül Üniversitesi İktisadi ve İdari Bilimler Dergisi 2015; 30: 145-65.

38. Migliore A. Sheltered Workshops. International Encyclopedia of Rehabilitation 2010.

39. Seyyar A. Uluslararası Boyutuyla Engelli Kota Sistemi. Kamu-İş 2012;6(1/2000) 